\title{
Finans ve Bankacılık Sisteminde Yapay Zekâ Kullanımı: Kullanıcılar Üzerine Bir Uygulama ${ }^{1}$
}

\author{
Ersin GÜMÜŞ², Batuhan MEDETOĞLU* ${ }^{*}$, Salih TUTAR ${ }^{4}$
}

Geliş Tarihi/Received: 18.02 .2020

Kabul Tarihi/Accepted: 21.04.2020

Araştırma Makalesi/Research Article

\section{ÖZET}

Finans sektöründe yapay zekâ uygulamalarının, bireylerin ödeme, tasarruf, birikim gibi alışkanlıkları üzerinde ne kadar etkili olduğunu ölçebilmek amacıyla gerçekleştirilen çalışmada öncelikle; finans sektörünün önemli kuruluşlarından biri olan bankaların tanımı, işlevleri, fonksiyonları anlatılmıştır. Çalışmada, yapay zekâ kavramı tanımlanmış ve finans sektöründe yapay zekânın işleyişi incelenmiştir. Yapay zekâ kullanımı finans sektöründe, maliyetleri azaltması, işlemlerin çabuk gerçekleştirilmesi, sunduğu güvenlik uygulamaları, her zaman ulaşılabilir olma yönleriyle kullanıcılara büyük avantajlar sağlamaktadır. Bu çalışmada yapay zekâ kullanımının finans sektöründe ve bankacılık alanında hem sistemi uygulayanlar hem de sistemi kullananlar tarafından ne kadar etkili olduğu ortaya konulmuştur. Çalışmada 500 kişiye anket çalışması uygulanmış ve sonuçlarına bakıldığında ise, kullanıcıların yaş, cinsiyet, meslek ve gelir dağılımı açısından yapay zekâyı kullanma biçimlerinin farklılık gösterdiği görülmektedir. Ankete katılım sağlayan kişilerin, kolaylık ve güvenilirlik faktörleri ile kullanıcıların yaş, gelir ve eğitim düzeyleri analiz edilmiştir. Ankete katılım sağlayan kişilerin yaş, gelir ve eğitim düzeylerinin artması, yapay zekâya olan güveni de arttırmaktadır. Finans sektöründe yapay zekânın etkin kullanımının, kullanıcılar açısından büyük kolaylık sağladığı sonucuna ulaşılmıştır.

Anahtar kelimeler: Bankacılık, Finans, Yapay Zekâ, Dijital Ürünler, Finansal Dönüşüm.

\footnotetext{
1Bu çalışma Ersin Gümüş tarafından İstanbul Ayvansaray Üniversitesi, Plato Meslek Yüksekokulu, Finans, Bankacılık ve Sigortacılık Bölümü'nde sunulan "Bankacılık Sisteminde Yapay Zekâ Kullanımı ve Etkileri", başlıklı bitirme projesinden yararlanılarak ve proje çalışması genişletilerek hazırlanmıştır.

2 Öğrenci, İstanbul Ayvansaray Üniversitesi, Bankacılık ve Sigortacılık Bölümü

3 Öğr. Gör., İstanbul Ayvansaray Üniversitesi, Finans, Bankacılık ve Sigortac1lık Bölümü

* Sorumlu yazar/Corresponding author

E-mail/e-ileti: batuhanmedetoglu@ayvansaray.edu.tr

4 Öğr. Gör., Sakarya Uygulamalı Bilimler Üniversitesi, Rektörlük
} 


\title{
Using Artificial Intelligence in Finance and Banking System: An
}

\section{Application on Users}

\begin{abstract}
In the study carried out in order to measure the impact of artificial intelligence applications on the habits of individuals such as payment, savings and accumulation in the finance sector, firstly; The definition, functions and functions of banks, one of the important institutions of the financial sector, are described. In the study, the concept of artificial intelligence is defined and the functioning of artificial intelligence in the financial sector is examined. In the financial sector, the use of artificial intelligence provides great advantages to users in terms of decreasing costs, performing transactions quickly, security practices, and being always accessible. In this study, it has been demonstrated how effective the use of artificial intelligence is in both the financial sector and the banking sector by those who use the system and those who use the system. In the study, 500 people were surveyed and when the results are analyzed, it is seen that the ways users use artificial intelligence differ in terms of age, gender, occupation and income distribution. The factors of convenience and reliability of the participants, and the age, income and education levels of the users were analyzed. The increase in the age, income and education levels of the people participating in the survey also increases the confidence in artificial intelligence. It has been concluded that the effective use of artificial intelligence in the financial sector provides great convenience for users.
\end{abstract}

Keywords: Banking, Finance, Artificial Intelligence, Digital Products, Financial Transformation.

\section{GİRIŞ}

Yapay zekâ uygulamaları bankalar için, pazar bilgisi elde etmek, bankalarda kullanılan bankacılık hizmetlerini müşterilere ulaştırmak ve iletişimi daha kolay şekilde artırmak için kullanılmaktadır. Bankalarda kullanılan yapay zekâ uygulamaları, bankanın imajının daha fazla güçlenmesi ve bünyesinde bulunan müşterileri tutmak amacıyla ve daha yeni müşteriler çekmeyi ön plana aldığından, şubelerdeki yükü biraz da olsa azaltmak için ve müşterilerine daha hızlı hizmet vermeyi amaçladığı için internet ve mobil bankacılık uygulamalarına müşterilerini yönlendirmeye çalışmaktadır. Ancak bilinmesi gerekiyor ki, bu sistemlerin kullanılabilmesi için güçlü altyapılar gerekmektedir. Bunun için bankalar teknolojiye ve 
özellikle yazılımlara yaptığı yatırımları artırmaktadırlar (Okumuş, Bozbay, \& Dağlı, 2010, s. 92).

Bankaların internet ve mobil bankacılık uygulamalarına yönelmeleri için değişik sebepler bulunmaktadır. Özellikle elinde bulundurduğu müşterilerini rakiplerine kaptırmamak ve rekabet ortamından geri kalmamak için bu uygulamalara yönelmektedirler. Bunun yanında genç nüfus yoğunluğu ülkemizde giderek artış gösterdiği için genç kitle oluşturmayı hedefleyen bankalar, maliyetleri de azaltmak için bu tür girişimlerde bulunmaktadırlar. İlk başlarda tanıtım ağırlıklı olarak internet sayfaları ile müşteriye yaklaşmaya çalışan bankalar, daha sonra müşterilere bir kullanıcı adı oluşturarak ve bir şifre göndererek hizmeti sunmaya başlamışlardır. $\mathrm{Bu}$ şekilde müşteriler kendi kullanıcı adları ve kendi belirledikleri özel şifreyle bankacılık hizmetlerine bu yolla ulaşabilmektedir (Parasız, 2011, s. 61-62).

Bankalar yapay zekâ uygulamaları sayesinde müşterilerine hızla ulaşmakta ve müşteriye ulaştırılan hizmetlerin sayısı günden güne artış göstermektedir. Bu sırada tabi ki bankalar arası yarış tüm rekabetiyle devam etmekte olduğu için en yeni ve en hızlı hizmeti sağlayan banka yarış içinde öne geçmektedir. Dolayısıyla internet ve mobil bankacılıkta gelinen bu noktada, şubede gerçekleştirilen tüm işlemler neredeyse bu uygulamalarda da yapılabilmektedir. $\mathrm{Bu}$ bağlamda hızla artan rekabet koşullarına uyum sağlamak isteyen firmalar teknoloji içeren yeni ürünler üreterek ve maliyetleri azaltarak, müşteri memnuniyetini artırarak yeni müşterilerin kazanılmasını hedeflemektedir (Işkın, 2012, s. 50).

Bankacılık sektöründe kullanılan yapay zekâ uygulamaları, kullanıcılara kolaylık sağlar mı ve ne ölçüde güvenilirdir? Bu çalışmanın amacı geleneksel bankacılık yöntemleri yanında, günümüzde sıklıkla kullanılan yapay zekâ uygulamalarının; kullanıcılar açısından iki faktörle işleyişini test etmektedir. Kullanıcılara sağlanan kolaylığın ve kullanıcıların bu uygulamalara olan güveninin; yaş, cinsiyet, meslek gibi faktörlere göre ne derece değişiklik gösterdiği ortaya konulmaya çalışılmıştır.

\section{BANKA VE BANKACILIK KAVRAMI}

Ekonomide finansal sistemin önemli kurumlarından biri konumunda bulunan bankalar, ülkelerin ekonomik yapıları ve gereksinimleri doğrultusunda kanunlar ile kontrol altına alınmıştır ve sürekli denetim altındadırlar. Yaptıkları görev ve fonksiyonları sebebiyle bankalar, hem kendi ülkelerinde hem de dünya çapında kendine özgü finansal kuruluşlar haline gelmiştir. Günümüzde bankalar, işlemlerin zorluğu ve çeşitliliğinden dolayı geleneksel dönemlerin bankalarından daha seçkin ve etkin bir kurum haline gelmişlerdir. Bankaların 
ekonomideki faaliyetleri ile yönetiminin niteliği de bu konuda önemli bir unsur haline gelmiştir (Doğan, 2012, s. 2).

Bankalar toplumun ihtiyacı olan hizmet arzı, kredi, yatırım, sermaye gibi alanlarda her işlemi gerçekleştirebilen, toplumun kullanılabilir kaynaklarına öncülük eden kurumlardır. Bankalar diğer bir yandan müşterilerden topladığı mevduatları ve diğer kaynaklardan yarattığı olanakları kullanarak, diğer bir deyişle para ticareti ve kredi ticareti yapan ve ekonomiye katkıda bulunan işletmelerdir. Diğer işletmelere kıyasla ise bankalarda para ile para değişimi yapılırken diğer işletmelerde ise para karşılı̆̆ı mal ve hizmet satın alınmaktadır (Aktaş, 2018)

Bankalar bireyler arası para akışına ve ödeme işlemlerine aracılık etmektedir. Yapılan bu hizmetler, EFT, Havale, Swift, Pos ile ya da doğrudan transfer ya da çek, senet, kredi kartı gibi vadeli ödeme araçlarıyla birlikte gerçekleşmektedir. Bankalar, yatırım yönünden değerlendirilecek olursa, kişilerin hesaplarında bulunan finansal varlıkları yönetirler, aracılık ederler ve danışmanlık yaparlar. Bunun yanı sıra bireylerin nakitlerini, menkul kıymetlerini, değerli eşyalarını saklama gibi hizmetleri bankalar tarafından verilmektedir (Güney, 2012, s. $5)$.

\subsection{Bankacılığın İşlevleri}

Toplumu oluşturan kitlelerden mevduat ve benzeri yollarla para toplayan, topladığı bu paraları da kredi gibi maliyeti yüksek işlemlerde kullanan ve ekonomide kaydi para yaratan finansal kurumlar olarak tanımlanan bankaların işlevleri aşağıda sıralanmaktadır (Gürtuna, 2005, s. 6);
$\checkmark \quad$ Finansal aracilik
$\checkmark \quad$ Diş ticareti fonlama ve ihracatı teşvik
$\checkmark \quad$ Kaynakların etkin kullanımını sağlamak
$\checkmark \quad$ Gelir ve servet dağılımını etkilemesi
$\checkmark \quad$ Kaydi para yaratma
$\checkmark \quad$ Para ve maliye politikalarının işleyişini sağlama
$\checkmark \quad$ Factoring
$\checkmark \quad$ Diş ticareti geliştirmek

\subsection{Bankacılığın Fonksiyonları}

5411 sayılı Bankacılık Kanunu'na göre bankaların fonksiyonları aşağıdaki gibi sıralanmıştır;

\footnotetext{
$\checkmark \quad$ Mevduat kabul eder.
} 
$\checkmark \quad$ Katılım fonu kabulü eder.

Nakdî, gayri nakdî her cins ve surette kredi verme işlemleri gerçekleştirir.

Nakdî ve kaydi ödeme ve fon transferi işlemleri, muhabir bankacılık veya çek hesaplarının kullanılması dahil her türlü ödeme ve tahsilat işlemleri yapar.

$\checkmark \quad$ Çek ve diğer kambiyo senetlerinin iştirası işlemleri gerçekleştirir.

$\checkmark \quad$ Saklama hizmetleri yapar.

$\checkmark \quad$ Kredi kartları, banka kartları ve seyahat çekleri gibi ödeme vasıtalarının ihracı ve bunlarla ilgili faaliyetlerin yürütülmesi işlemlerini gerçekleştirir.

$\checkmark \quad$ Efektif dahil kambiyo işlemleri; para piyasası araçlarının alım ve satımı, kıymetli maden ve taşların alımı, satımı veya bunların emanete alınması işlemlerini gerçekleştirir.

$\checkmark \quad$ Ekonomik ve finansal göstergelere, sermaye piyasası araçlarına, mala, kıymetli madenlere ve dövize dayalı; vadeli işlem sözleşmelerinin, opsiyon sözleşmelerinin, birden fazla türev aracı içeren basit veya karmaşık yapıdaki finansal araçların alımı, satımı ve aracılık işlemlerini yapar.

Sermaye piyasası araçlarının alım ve satımı ile geri alım veya tekrar satım taahhüdü işlemlerini gerçekleştirir.

$\checkmark \quad$ Sermaye piyasası araçlarının ihraç veya halka arz yoluyla satışına aracılık işlemlerini gerçekleştirir.

$\checkmark \quad$ Daha önce ihraç edilmiş olan sermaye piyasası araçlarının aracılık maksadıyla alım satımının yürütülmesi işlemlerini yapar.

$\checkmark \quad$ Başkaları lehine teminat, garanti ve sair yükümlülüklerin üstlenilmesi işlemleri gibi garanti işlerini yapar.

$\checkmark \quad$ Yatırım danışmanlığı işlemlerini gerçekleştirir.

$\checkmark \quad$ Portföy işletmeciliği ve yönetimi yapar.

$\checkmark \quad$ Hazine Müsteşarlığı ve/veya Merkez Bankası ve kuruluş birlikleri nezdinde oluşturulan bir sözleşme kapsamında üstlenilen yükümlülükler çerçevesinde alım satım işlemlerine ilişkin piyasa yapıcılı̆̆ı yapar.

$\checkmark \quad$ Faktöring ve forfaiting işlemleri gerçekleştirir.

$\checkmark \quad$ Bankalar arası piyasada para alım satımı işlemlerine aracılık eder.

$\checkmark \quad$ Finansal kiralama işlemleri yapar.

$\checkmark \quad$ Sigorta acenteliği ve bireysel emeklilik aracılık hizmetleri eder.

$\checkmark \quad$ Kurulca belirlenecek diğer faaliyetleri gerçekleştirir.

Bankalar mevduat toplar, kredi verir, para ve kredi uygulamalarına destek verir, aracılık faaliyetleri yapar, kiralık kasalarında kişilerin değerli menkul kıymetlerini korur ve saklar, 
ülkenin ekonomisine doğrudan etki eder ve ülkenin kalkınmasında önemli rol oynar ve yönlendirir. Bankaları, düşük faiz oranıyla mevduat hizmeti sunan ve yüksek faiz oranıyla kredi veren ve aşırı kâr eden kurumlar olarak tanımlamak doğru olmayacaktır. Bankalar, elinde bulunan finansal ürünler ve etkin fon yönetimiyle, finans sektörüne yön veren kurumlar arasındadır (Takan, 2001, s. 2).

Bankacılık temelde bir risk transfer mekanizması olarak da görülebilir. Buradaki risk kavramı, beklenen ya da istenen işlerin yerine getirilmemesi, beklenilen gelişmelerin gerçekleşmemesi veya hiç beklenmeyen gelişmelerin ortaya çıkması bu durumda da zarara uğramasıdır (Aras, 1999, s. 12).

Günümüzde bankacılık sistemi fon fazlası olan birimlerden toplanan mevduatların, fon açığı olan birimlere kredi olarak verilmesi esasına dayanmaktadır. Böylece bankalar tasarrufların yatırıma dönüşmesinde önemli bir rol oynamaktadır (Karabıyık, 2004, s. 123).

\section{BANKACILIKTA FINANSAL DÖNÜŞÜM}

Teknolojik gelişmeler sonucunda bankacılık sektöründe geleneksel dağıtım kanalların yerine şubelerinde tercih ettiği yeni dağıtım kanalları ortaya çıkmıştır. Bankacılık sektörü günümüz sektörleri arasında en gözde ve en dinamik sektörlerden birisidir. Geçmişe bakıldığında müşteriler bankaları bulundukları yere göre seçerken, şimdi ise bankalar müşterilerine internet kullanıcıları ile dünya genelinde hizmet sunmaktadır. İnternet Bankacılığının, ATM'lerden sonra bankacılık sektöründe önemli bir devrim niteliğinde olduğu düşünülmektedir (İşler, 2015).

\section{1. İnternet Bankacılığı ve Mobil Bankacılık Uygulamaları}

Teknolojinin bu denli hızla geliştiği dünyada, yeni ve çok fonksiyonlu cihazlarda yaygınlaşmaktadır. İnsanların hayatını kolaylaştırmak için gelen bu yenilikler bankalar tarafından müşterilere sunulmaktadır. Böylece firmaların maliyetlerinin düşürülmesinin yanında rekabet ortamında öne çıkmasını sağlamada ve müşteri memnuniyetinin de arttırılmasına yardımcı olmaktadır. Bu tür avantajları sebebi ile teknolojik gelişmelerin hızlı ve güvenilir bir şekilde entegre edildiği sektörlerin başında bankacılık sektörü gelmektedir. Ek olarak teknolojik gelişmelerin uygulandığı sektörlerin başında yine bankacılık sektörü göze çarpmaktadır. Özellikle 2000'li yılların sonrasında teknolojik gelişmeler hızla değişmiş, birçok yeni elektronik araç hayatımıza girmiştir. Elektronik bankacılığın ilk örnekleri ATM, Pos cihazı, telefon gibi araçlar üzerinden sınırlı olarak gerçekleştirilebilirken, günümüzdeki sistemler eskiye nazaran daha çok geliştirilmiş ve işlem çeşitliliği yönünden artış sağlanmıştır. 
Bununla birlikte internet, cep telefonu, kiosk gibi e-bankacılık kanalları da müşterilerin hizmetine sunulmuştur (Armağan, 2016, s. 411-436).

Teknoloji alanındaki gelişmeler, ülkemizde ki bankacılık sektörünün hızla gelişmesine ve hızla kitlelere ulaşmasında yardımcı olmuştur. Bilişi̇m teknolojilerindeki değişim, bilginin toplanması, depolanması, işlenmesi ve dağıtımının yönetim maliyetlerini azaltmakta ve süreci daha kısa şekilde işlemesini sağlamaktadır. Diğer taraftan ise zaman ve mekân kavramını ortadan kaldırmakta, müşterilerin hızlı bir şekilde bankacılık ürünlerine ulaşmasını sağlamaktadır. Bankalarda ise risk izleme ve denetleme sistemleri teknoloji kullanımının artmasıyla daha efektif hale gelmiştir (TBB, 2012).

\subsection{Internet Bankacılığı}

İnternet bankacılı̆̆ zaman ve yer kavramından söz edilmeksizin, bir bilgisayar ile bankacılık hizmetlerinin internet üzerinden müşterilere sunulduğu dağıtım kanalı olarak ifade edilmektedir. İnternet erişimine sahip olabilen her bilgisayar ile birlikte 24 saat boyunca erişim sağlanabilen bir dağıtım kanalıdır. Bankacılık sisteminde de çağın iletişim sistemi olarak öncüsü olan internet kullanımın yaygınlaşması klasik bankacılıkta bir devrim olarak görülmektedir. Öyle ki, para çekme dışında diğer tüm bankacılık hizmetlerinin internetteki sanal banka şubelerinden verilmesi mümkün hale gelmiştir. Tüm işlemlerin evden yapılması, fiziki bir paranın ortada dolanmaması gibi etkenler şubesiz bankacılığı gündeme getirmiştir (Parasiz, 2007, s. 367).

Sanal bankalar kullanıcılarına, fiziki bir mekân olmaksızın bankacılık hizmetlerinden yararlanabilme imkânı sunmaktadır. Teknoloji diğer sektörleri peşinden sürüklemekle birlikte değişimi de gerekli kılmaktadır. Bu gelişmeler bankacılık sektörünü, hızla gelişen ve yayılan teknolojiye ayak uydurma zorunluluğunu getirmiştir. Bankalar, gelişmeleri yakından takip etmesi gereken sektörlerden biri haline gelmiştir. Müşterinin bankacılık hizmetlerini alması için evinden bilgisayar ile birlikte internete bağlı şekilde erişim sağlayabildiği internet bankacılığı, günümüz teknolojisinde daha da ileri giderek cep telefonlarımıza kadar ulaşmayı başarmıştır (Keskin, 2017).

İnternet bankacılığı bilgisayar kullanan müşteriler için, daha uygun bir dağıtım kanalı olduğu için toplumdaki okuryazarlık oranı, bilgisayar kullanım oranı giderek artmakta ve bu dağıtım kanalı etkisini gün geçtikçe arttırmaktadır. İnternet bankacılığı kullanan müşteriler internet yoluyla erişim sağladıkları sanal şubede kendi mevduatlarını, yatırımlarını, kredilerini veya borçlarını takip etme şansına sahiptirler (Eriş, 2013, s. 171). 


\section{3. İnternet Bankacılığı İle Yapılabilecek İşlemler}

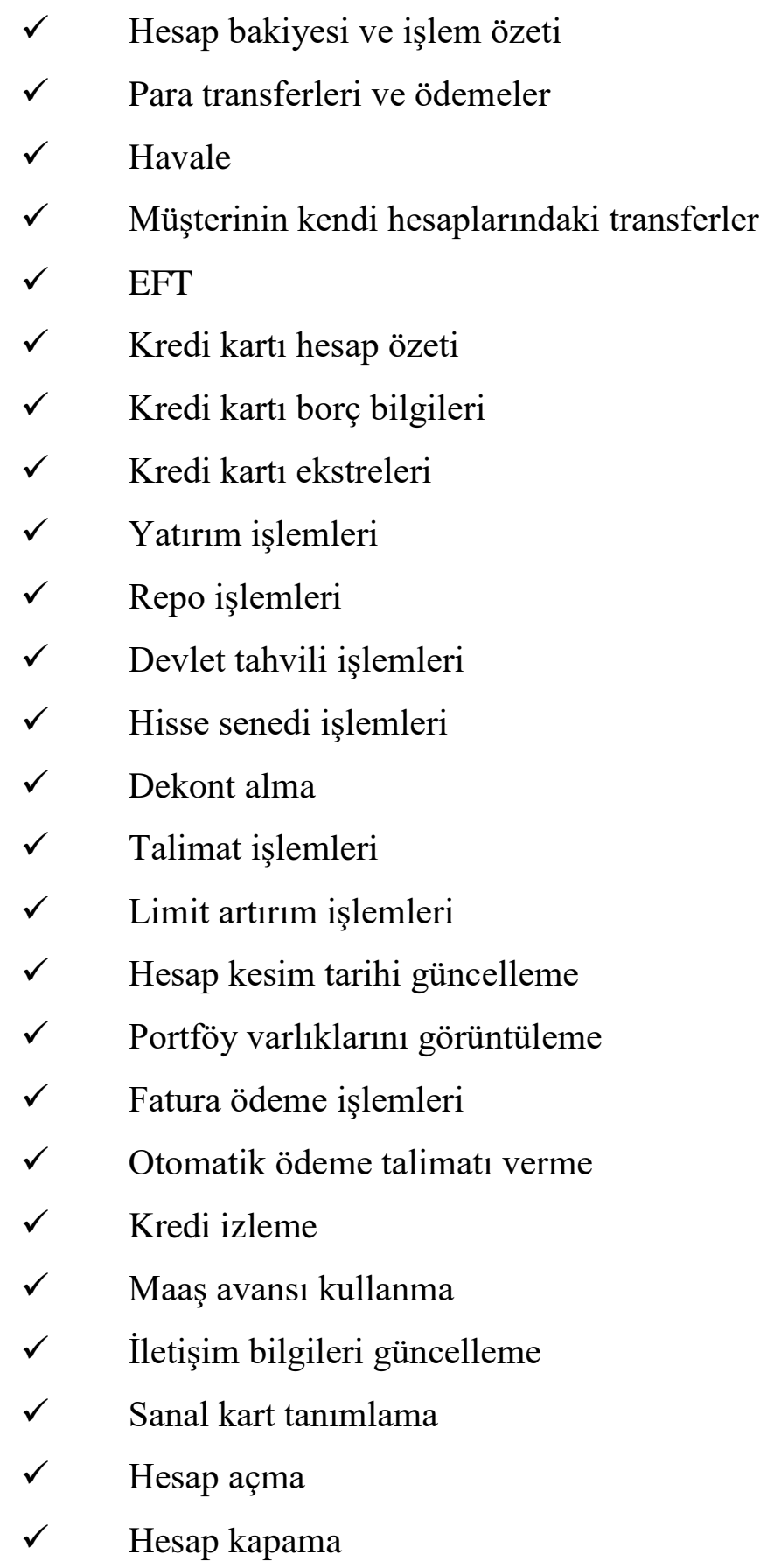

Hesap bağlama gibi işlemler zaman ve mekân kavramından bağımsız olarak internet erişimine sahip bir bilgisayardan istenildiği zaman yapılabilmektedir (Denizbank, 2019). İnternet bankacılığı, şube bankacılığı ile karşılaştırıldığında, kurumlara birçok avantaj sunmaktadır. Bu avantajlar, müşteri odaklılığının artması, şube maliyetlerinde görülen azalma, ürünlerin yenilenmesi ve çeşitlendirilmesi, coğrafi bölgeye ve zamana bağlı kalmaksızın hizmet sunma olarak sıralanabilir. İnternet bankacılığının müşterilere sağladığı avantajları ise bir hesabın anında açılıp anında kapatılması, işlem maliyetlerinin daha düşük seviyede olması, bankacılık hizmetlerinin daha kolay yapılabilmesi, hızlı kredi alma firsatlarının sunması, 
bankacılık işlemleri açısından zaman tasarrufu gibi faydalar sağlamaktadır (Pala \& Kartal, 2010, s. 44).

Yeni bir dağıtım kanalı olarak da bilinen internet bankacılığı bankalar tarafından daha fazla potansiyel müşterilere daha düşük maliyetle benzer kalitede karmaşık ürünler sunabilmek ve yer zamandan bağımsız olarak kesintisiz iletişimi sağlamayı amaç edinmişlerdir. Şubelerdeki operasyonel işlemlerin maliyetleri bankalar için son derece önemlidir. Bankalar da bu maliyetlerin önüne geçebilmek için farklı dağıtım kanalları aramayı kendilerine amaç edinmişlerdir. ATM, internet bankacılığı ve telefon bankacılığı bu maliyetleri önemli ölçülerde azaltmıştır. Doğal olarak da bu maliyetlerin azalması dağıtım kanallarının müşteriler tarafından yoğun bir şekilde kullanımı ve desteklemesiyle gerçekleşmiştir (Önder, 1999, s. 55).

\subsection{Mobil Bankacılık}

Mobil bankacılık, müşterinin bir akıllı telefonu vasıtasıyla bankayla iletişimde olduğu bir uygulamadır. Kablosuz teknolojide ve mobil cihazların yaygın kullanımında, iletişimde, işlemlerde, alışverişlerde ve ticarette çok büyük iş firsatlarının doğmasını sağlamıştır. Yüksek veri aktarım hızı sayesinde daima online olan teknoloji, mobil cihazların çok yüksek seviyedeki bilgiyi ve hizmeti gerçeğe dayalı olarak ulaşmasına ve bilgi alıp göndermesine imkân sağlamıştır. Mobil bankacılık, elektronik bankacılığın bir alt kümesi olarak tanımlanmaktadır (Barutçu, 2010, s. 13).

Mobilite kavramı, hareket halinde olmayı ifade etmekte ve sabit bir yapı taşımama özelliği içermektedir. Mobil araç, taşınabilir olduğundan herhangi bir sabit noktaya, kablolara ya da bir cihaza bağlı kalmadan taşınabilmektedir. Bu özellik aynı zamanda sürekli bir hareket halinde olmayı da beraberinde getirmektedir. Mobil finansal hizmetler konusunda toplumda artan bir oranda pozitif yönde algı oluşturmuştur. Bunun sebebi temel olarak, toplumda mobil telefon kullanım oranının oldukça yükselerek, dünya ekonomilerinin entegrasyonunun mobiliteyi arttırması olarak gösterilebilir. Böylece mobil hizmetler lüks değil bir zorunluluk haline gelmiş, toplumdaki genç kesim modern bilgi ve iletişim hizmetleri konusunda hayranlık duymuş ve mobil cihazlar bankacılık hizmetlerine ulaşmada önemli bir noktaya gelmiştir (İşler, 2015).

\subsection{Finansal Teknoloji (Financial Technology) Kavramı}

Finansal Teknoloji (Fintech), finansal hizmetlerin daha hızlı ve verimli bir şekilde ve daha kolay yöntemlerle verilmesini ifade eden birtakım yenilikleri ifade etmektedir. Mobil ve online ortamlarda oluşturulan, finansal olarak ifade edilen işlemlerin birleştirilip teknolojinin getirdiği yeniliklerden sadece biri olarak ifade edilmektedir. Fintech sadece ülkemizde değil 
dünyada da sık kullanılan bir sistem haline gelmiştir. Fintech mobil ödeme araçları, para transfer işlemleri gibi birçok farklı alanda yenilikler içeren teknolojiyi etkisi altına almıştır (Döldöş, 2017).

Fintech teknolojisinin tercih edilme sebeplerinden bahsedecek olursak, kullanıcıların her an hesaplarına erişebilmeleri, bu hesaplar için bir yerden kalkıp başka bir yere gitmemeleri, fatura ödemek için bile şubeye gitmemeleri, vakit kazanmak amacıyla işlemleri mobil telefonlardan yapılabilme imkânı sayılabilmektedir. Bu teknolojinin önemli unsurlarından birkaçı ise kişiye özel verilen tavsiyeler ya da bir yetkiliye anında ulaşabilme olarak görülmektedir (Döldöş, 2017).

Bankacılık sektöründe yapılan işlemleri daha kolay ve daha az maliyet ile gerçekleştirebilen Fintech teknolojisi, iş dünyasını da baştan aşağıya yenilemeyi planlamaktadır. Bankalar ve müşteriler arasında ilişkileri önemli boyutta değiştiren bu teknoloji, bankacılık sektöründen de pazar çalmaya başlamış Fintech şirketleri bireyden bireye para transferlerini ve finansal çözümler sağlayarak önemli sayılabilecek başarılar elde etmiştir. Finans sektöründeki müşterilerin giderek artan teknolojik ürünler ve çözümler istemesi Fintech sistemine de bir yükseliş kazandırmıştır. Fintech, bankacılık sektörü ile başlayan mobil ve online uygulamaları da daha sık kullanılabilir hale getirmiştir (Dişbudak, 2018).

Fintech, kişiselleştirilmiş çözümler geliştirerek bankacılık sektörü için dijital ürünleri ön plana çıkarıp, müşteriler için yenilikçi ve sürdürülebilir ürünler sunmaktadır. Fintech, finans sektöründe yarattığı yenilik ve kolaylıklar gibi hizmetlerle ön plana çıkmaktadır. Bunun yanı sıra finans sektörü dışındaki kullanıcılara da ulaşarak daha fazla müşteri deneyimine odaklı şekilde çalışmalarını sürdürmektedir. Fintech, firmaları mobil ve dijital ortamlarda yarattı̆̆ yeniliklerle finans sektörü için vazgeçilmez bir yenilik haline gelmiştir (Codevist, 2018).

Ülkemiz sınırları içinde hızla büyüyen Ketchup Loyalty Marketing, İnfodif Yazılım, Ödeal İşyerim, Monitise, Paraşüt, Iyzico gibi firmalar kuruldukları yıldan bu yana önemli ölçüde sermayelerini kat ve kat üstüne çıkarmayı başarmışlardır (Soydan, 2016). Dünya üzerinde adını duyurmuş Stripe, YapStone, BrainTree, Adyen, Addepar gibi Fintech şirketleri de önemli ölçüde büyüme sağlamışlardır (Fintech, 2017).

\subsection{Kart Doğrulama Kodu}

Card Validation Value kelimelerinin kısaltılmasıyla CVV adını almış bu yenilik, bankalarca müşterilere sunulan kartlarda güvenlik sağlamak amacıyla oluşturulmuş bir koddur. 3 haneden oluşur ve kod sadece Mastercard ve Visa kartlarında bulunmaktadır. 1 Ocak 2001 
tarihinden itibaren bütün Visa kartlarda kullanılması zorunlu hale gelmiştir. Kodun basımı ise kredi kartlarındaki gibi kabartma baskı değil, düz bir baskıyla yapılmaktadır (Sallı , 2019).

İnternet üzerinden kredi kartı ile yapılan alışverişlerde kullanılan üç haneli kodun şimdiki haliyle pek güvenilir olmadığı düşünülmektedir. Bütün kart dolandırıcılıklarının \%65' inde kartın o sırada alışveriş yapan kişinin yanında olmadığı belirtilmektedir. Fakat CVV kodunun sık sık yenilenmesi durumunda, kişinin kartı bilgileri ele geçirilmiş olsa dahi dolandırıcılık ihtimalinin azaltılabileceği düşünülmektedir.

Fransız dijital ödeme şirketi Oberthur Technologies tarafından sağlanan dinamik CVV kodu tam olarak bu yönde çalışmaktadır. Belirli aralıklarla CVV kodunu değişmektedir ve olası dolandırıcılıkların önüne geçilebilmektedir (Sönmez, 2017).

Kredi kartları üzerinden silinen CVV kodları ise kullanımı etkilememektedir ve internet üzerinden yapılan alışverişlerde kod girilerek alışveriş tamamlanmaktadır. ATM kullanımlarında veya mağazalarda, reel alışverişlerde gerek duyulmayan CVV kodu, sadece internet üzerinden yapılan alışverişler için gerekli bir koddur. CVV kodu silinen ve kodu unutan kullanıcılar için ise CVV2 kodu ilk kart alımlarında sunulmaktadır. CVV2 kodları, kredi veya banka kartı alırken verilen bir tür sanal kart koddur. Sanal kart kullanımlarında ekstra güvenlik için kullanılabilmektedir (Gülyüz, 2018).

\subsection{Mobil Uygulamalardan Ödeme Yapabilme İmkânı}

Google Pay, Apple Pay, PayPal, Google Wallet, Skrill, Alipay, Masterpass, Samsung Pay gibi farklı birçok uygulama dijital cüzdan ödemeler için kullanılmaktadır. Bu cüzdanlara kaydedilen kartlar sayesinde, bir kartın olmasına gerek kalmadan, ödemeler bu uygulamalar üzerinden yapılabilmektedir. Örnek olarak Apple Pay, ödeme sırasında ödeme onayı almak için kullanıcının parmak izini onay olarak almakta ve ödeme işlemi bu şekilde gerçekleşmektedir. Bu sırada yapılan bu işlemler dijital ortama aktarılmış olmaktadır (Sönmez, 2017).

Dijital cüzdan sistemi dünya üzerinde hızlı büyüyen bir sistem haline gelmişken, ülkemizde de aynı şekilde büyümekte ve şekil almaktadır. Mobil ödeme işlemleri kullanıcılar için çözüm sağlarken, girişimciler için yeni fikirler ve fursatlar sunmaktadır. Dijital devrim sayesinde nakit para taşımak ve fiziki bir cüzdana sahip olma zorunluluğu neredeyse ortadan kalkmaktadır. Bunun yerine ödemeler cep telefonları ya da mobil uygulamalara taşınmakta ve işlemler daha hızlı ve kolay bir şekilde yapılmaktadır. Bunun yanı sıra mobil ödeme işlemlerinin, yakın gelecekte büyük tutarlara ulaşacağı düşünülmektedir (Yalçın, 2018). 


\subsection{Teknolojik Taşınabilir Ödeme Cihazları}

Kullanıcının giyerek kullandığı teknolojik cihazların genel adına giyilebilir ödeme cihazları adı verilmektedir. Giyilebilir teknoloji, bir akıllı saat, bir akıllı şort veya akıllı saat olabilir. Bu teknolojinin tam anlamıyla anlaşılabilir olduğu dönem ise 2015 yılında Apple tarafından piyasaya sunulan Apple Watch tipi giyilebilir ödeme cihazıdır. Giyilebilir teknolojilerin türleri ise gövde odaklı giyilebilir teknoloji ürünleri, baş odaklı giyilebilir teknoloji ürünleri, bacak ve ayak odaklı giyilebilir teknoloji ürünleri, el ve kol odaklı giyilebilir teknoloji ürünleridir (Öner, 2018).

Teknolojinin mobil alanlarda getirdiği en son yenilik olarak belirtilen mobil ödeme sistemleri, giyilebilir teknolojilerinin de gelişmesiyle birlikte bu ürünlere de taşınmış oldu. Giyilebilir teknoloji ürünleri için Apple Pay, Samsung Pay ve Android Pay gibi birçok şirketin kendi ürünleri için çözüm olarak Mastercard ve Visa gibi kart üretici firmalarla iş birliği sağlayarak bu alanda çalışmalarını sürdürmektedirler. Giyilebilir ödeme sistemleri olarak adlandırılan bu ödeme sistemi ile akıllı saat ve akıllı bileklik gibi teknolojik ürünlerle kullanıc1larına taksilerde, benzinliklerde, restoran veya kafe gibi yerlerde kolayca ödeme imkânı sunmaktadır (Öner, 2018).

\subsection{Kasaya Gerek Duymadan Ödeme Kolaylığı}

Akıllı telefonlar, hayatımızın hemen hemen her anında yanımızda yer almaktadır. Akıllı telefonlar ile birlikte, mobil ödeme sistemleri de geliştirilmeye ve alışkanlıklar değişmeye devam etmektedir. Akıllı pos cihazları ile beraber, mobil ödeme teknolojilerinin birleşimi, artık kasaya gerek duymadan, sıra beklemeden, hızlı bir şekilde alışverişinizi tamamlamanıza yardımcı olmaktadır (Alkan \& Küçükyılmaz, 2018).

Dijital cüzdan uygulamalarından olan BKM Express, Kanyon AVM ve D\&R iş birliğiyle yapılan çalışmada, BKM Express üyeleri, Kanyon cam odada alışverişlerini bir kasiyere ihtiyaç duymadan, istedikleri ürünün fiyatını ödeyip mağazadan ayrılabilmektedir. Ödeme için ise BKM Express kullanıcıları seçtikleri ürünlerin barkodunu KPay pos cihazına okutmakta, sonrasında pos cihazının ekranında oluşan QR kodunu cep telefonlarında bulunan BKM Express uygulaması ile okutarak ödemelerini tamamlamaktadır (Şahin, 2018).

Bunun yanı sıra bir internet üzerinden alışveriş yapılabilen Amazon sitesi, kendi bünyesinde oluşturduğu Amazon Go isimli süpermarkette bir kasa bulundurmakta ve müşteriler alışveriş yaptıkları esnada kimlikleri kameralar ile sensörler tarafından tanımlanmakta ve aldıkları ürünlerin fiyatları Amazon Go hesaplarından düşülmektedir. Bu durumda kasada 
ödeme yapmak için beklenmemekte ve paraya dair hiçbir fiziksel işlem gerçekleşmemektedir (Sönmez, 2017).

\subsection{QR Kodu ATM'ye Okutarak Para Çekme İşlemi}

Birçok banka, ATM'lerden kartsız şekilde para çekmek için çeşitli yöntemler geliştirmektedir. Akıllı telefonlarda bulunan yakın alan özelliği ile karta gerek duymadan ATM’ye bağlanmak mümkün olmakta ve burada da fiziksel bir para işlemi söz konusu olsa da parayı çekme işlemi dijital olarak gerçekleşmektedir (Sönmez , 2017).

ATM'ye dokunmadan para işlemini gerçekleştirebilmek için bankalarca sunulan mobil bankacılık uygulamalarına müşteri numarası ve şifre ile giriş yapılması, uygulama menüsünden para çekme sekmesini kullanarak çekilmek istenilen tutarın tuşlanması gerekmektedir. $\mathrm{Bu}$ sırada telefonun kamerası açılmakta, telefonun ekranına gelen QR kodun işlem yapılan ATM' ye okutulması gerekmektedir. Başarılı bir şekilde okutulan kodun sonrasında para çekme işlemi tamamlanmaktadır (Türkiye İş Bankası, 2016).

\subsection{Araba İçine Yerleştirilmiş ATM'ler}

Polonya’ da bulunan İdea Bank, bir araba içine yerleştirdiği ATM ile müşterilerine gece saatlerinde para çekme, para yatırma işlemleri gibi hizmetler sunmaktadır. 2015 yılında faaliyete geçirilen bu yenilik, arabaya yerleştirilen ATM cihazının talep edilen yerlere gitmesi şeklinde çalışmaktadır. Müşterilerin Android veya IOS cihazlarından indirebilecekleri uygulamayla, kendilerine yakın mobil ATM'leri görebilmekte ve kullanabilmektedir. Ayrıca banka müşterileri tarafından taksi olarak da kullanılabilen bu Mobil ATM'ler, müşterilerin telefonlarındaki uygulama ile yakınlarındaki restoranlardan yemek temini yapabilmesini de sağlamaktadır (Market Palace, 2016).

\section{FINANS VE BANKACILIK SEKTÖRÜNDE YAPAY ZEKÂ}

Yapay zekâ uygulamalarının bankalar ve banka müşterileri açısından birçok noktada kullanımına etki ettiğini, yapılacak işlemlerde kolaylıklar sağladığını ve internet erişiminin sağlandığı ortamlarda bireyler için zaman ve yer kavramlarını ortadan kaldırdığını söylemek mümkündür. İnternet ve mobil bankacılık uygulamalarını da beraber geliştiren yapay zekâ uygulamaları, günümüz bankacılık sektörü içinde getirdiği yeniliklerle bankalar için de maliyetleri azaltmış ve azaltılan bu maliyetlerle bankalar yeni girişimlere ve yeni yatırımlara yönelebilmiştir. Bankalar, müşteriler için hizmet kalitesini en üst seviyeye ulaştırmak için yapay zekâ uygulamalarına önem vermektedir. 
Yapay zekâ uygulamalarının hızla gelişmesi ve insanlarla birebir iletişimi de beraberinde getirdiği için, merkezi insan olan hizmet faaliyetleri için büyük ölçüde önem taşımaktadır. $\mathrm{Bu}$ uygulamalar sayesinde insanlar banka şubelerine gitmeden akıllı telefonlarından ya da internet erişimi sağlayabildikleri bilgisayarlarından pek çok bankacılık işlemlerini yapabilmektedirler. Teknolojinin bu denli gelişmesi yapay zekâ uygulamalarının da gelişmesini sağlamıştır. Bunun sonucunda ise internet alanında da birçok gelişme yaşanmış ve bu gelişmeler iletişimi de etkilemiştir. Sözü edilen bu gelişmeler ise finans ve bankacılık sektörünün de gelişimine büyük katkı sağlamıştır. Finans ve bankacılık sektörü ise gelişen bu yapay zekâ uygulamalarına ayak uydurarak hizmetlerini bu kanallardan sunmaya ağırlık vermiştir.

Yapay zekâ uygulamalarında gelişen bu süreçler insan hayatını olumlu yönde etkilemiş, bankacılık sektörüne ise önemli bir boyut kazandırmıştır. Günümüzde banka müşterileri yapay zekâ uygulamalarını kullanarak banka şubeleriyle veya banka çalışanlarıyla bir iletişim sağlamadan kendi işlemlerini kolaylıkla gerçekleştirmekte ve sağlanan bu kolaylık doğrultusunda hizmet kalitesini mobil uygulamalar üzerinden beğenip beğenmediklerini puan sistemiyle yorumlayıp bankalara iletebilmektedirler. Bunun sonucunda uygulamayı kullanan müşteriler kendilerine vakit kazandıran yapay zekâ uygulamalarına daha çok yönelmektedirler.

İnsanların hayatlarını kolaylaştıran teknoloji, bankacılık sektörü için de önemli gelişmeler sağlamış, banka ve banka müşterileri için maliyeti ve zaman kavramını minimize eden bir sistem haline gelmiştir.

Yapay zekâ uygulamaları, bankacılık sektörünün vazgeçilmez bir parçası olmuştur ve bankacılık alanında birçok yeniliğe ve değişikliğe yol açmıştır. Bu sebeple yapay zekâ uygulamaları gerek bankacılık faaliyetleri gerekse dağıtım kanallarının gelişmesinde önemli rol oynamıştır. Bu değişikliklerin meydana gelmesi ise rekabet ortamını oluşturmuş ve bankalar hizmetlerinde çeşitli yeniliklere gitmek zorunda kalmıştır.

Türk bankacılık sektöründe yapay zekâ uygulamalarının kullanımına sayısal olarak bakıldığında, hizmetlerden faydalanan banka müşterilerinin sayısında yüksek artış yaşandığı, yapay zekâ uygulamaları üzerinden yapılan işlemlerin hacminin büyüdüğü ve yüksek rakamlara ulaştığı görülmektedir. Tüm bu bilgiler üzerinden yorum yapmak gerekirse, Türk bankacılık sektöründe yapay zekâ uygulamalarının önemi her geçen gün daha fazla artmakta, bankalarca yoğun şekilde kullanılan bir sistem olduğu söylenebilmektedir. 
Rekabet yapısı içinde yapay zekâ uygulamaları, bankaların kullandığı önemli araçlardan birisi olmuştur. İnternet, bankacılık sektöründeki işletmecilik anlayışına da etki etmiş ve bu etki bankaların sunduğu hizmet kalitelerine de yansımıştır. Bankalar, ürünlerini internet üzerinden müşterilerine iletmeye başlamasıyla birlikte, hız, zaman ve maliyet açısından önem kazanan bu günlerde, internet bankacılığı ile sağlayabileceği en yüksek faydayı sağlamayı planlamaktadırlar. Bunu da maksimum müşteri memnuniyeti ile yerine getirmeyi hedeflemektedir.

Bankaların bir strateji ortağı sayılabilen yapay zekâ uygulamaları, bankalar için de bir alternatif olarak görülmektedir. Banka şubelerindeki müşterilerin yoğunluğu ve zaman zaman yaşanan sıra kuyruklarının getirdiği olumsuzluklar nedeni ile bu uygulamalar alternatif bir araç haline gelmiştir. Dijital çağ olarak adlandırdığımız dönem, gerçekleştirilen işlemlerin daha hızlı ve kolay yoldan, daha az maliyet ile gerçekleşmesine imkân vermiştir. Yaşanan bu değişimler de bankacılık sektörünü yakından ilgilendirmektedir (Ercişli, 2007).

Yapay zekâ uygulamalarının gelişmesi ile birlikte finansal olarak verilen hizmetler de bu gelişimin gösterdiği yola göre şekil almaktadır. Finans sektörünün en önemli unsurlarından biri olan bankalar, elektronik bankacılığın gelişiminde önemli rol oynamışlardır. Yapay zekâ uygulamalarına örnek olarak gösterilebilecek ATM'lerin, başlarda ilgi görmeyeceği düşünülmüş, ilerleyen y1llarda ise bu fikrin doğru olmadığı ortaya konulmuştur. Bankacılık sektörü açısından rekabetin artması ise yeni hizmetler ve çeşitliliği arttırmış, zaman ve maliyeti minimize eden yapay zekâ uygulamaları ise bu hizmetlerin gelişmesinde önemli rol oynamıştır (Özcan, 2007).

\section{ARAŞTIRMANIN YÖNTEMI VE BULGULAR}

Araştırmanın konusu 'Bankacılık Sisteminde Yapay Zekâ Kullanımı ve Etkilerini Ölçme Anketi' başlığıyla belirlenmiştir. Araştırmada değişen ödeme alışkanlıkları, gelişen teknoloji ve finans sektöründe yaşanan gelişmelerin bireyler üzerindeki etkisi ölçülmeye çalışılmıştır. Bireylerin finans sektöründe yapay zekâ kullanımı, yaş, cinsiyet, gelir durumu gibi değişkenlerle ölçülmüştür. Araştırma, bireylerin yapay zekâyı nasıl kullandığını ve yapay zekâya olan güveni ortaya çıkarmayı amaçlamaktadır. Yapay zekâ uygulamaları genel olarak, bireylerin işlemlerini yapabilen yazılımlardan oluşmaktadır. Bu yazılımların hem bireylere sağladığı hem de kurumlara sağladığı faydalar ortaya çıkarılmıştır. Temel olarak 'bireyler yapay zekâ uygulamalarını ne sıklıkla kullanmaktadır ve yapay zekâ uygulamalarına ne kadar güvenmektedir' sorusuna odaklanılmıştır. 
Çalışmada katılımcıların bankacılık sektöründe yapay zekâ kullanımı ile ilgili güvenilirlik algıları ile kolaylık/ulaşılabilirlik algılarını tespit etmek amacıyla anket yöntemiyle veriler toplanmıştır. Ankete toplam olarak 500 kişi katılmıştır. Anket ile ilgili katılımcıların cinsiyetleri, yaş aralıkları, eğitim durumları, aylık kişisel gelirleri ve 19 adet yapay zekâ ile ilgili soru yöneltilmiştir.

Toplanan verilerden elde edilen sonuçların güvenilirliğini ölçmek için SPSS paket programında güvenilirlik analizi ve elde edilen verilerin parametrikmi, nonparametrikmi olduğunu belirlemek için varsayımlar kontrol edilmiştir. SPSS paket programında gerçekleştirilen analiz sonuçları aşağıda gösterilmiştir.

Tablo 1. Güvenilirlik analizi

\begin{tabular}{|c|c|c|}
\hline Cronbach's Alpha & Standardize edilmiş Cronbach's Alpha & $\mathrm{N}$ \\
\hline, 941 &, 940 & 23 \\
\hline
\end{tabular}

Katılımcılardan elde edilen verilere güvenilirlik analizi gerçekleştirildiğinde Cronbach's Alpha değeri 0,941 çıkmıştır. Bu değerden hareketle veriler ile gerçekleştirilen analizlerin güvenilirliği \%94 olduğu söylenebilir.

Tablo 2. Normallik testi

\begin{tabular}{|l|c|c|c|c|c|c|c|c|}
\hline & \multicolumn{3}{|c|}{ Kolmogorov-Smirnov } & \multicolumn{3}{c|}{ Shapiro-Wilk } & \multicolumn{2}{c|}{ Niteleyiciler } \\
\cline { 2 - 9 } & İstatistik & $\begin{array}{c}\text { Serbestlik } \\
\text { Derecesi }\end{array}$ & $\begin{array}{c}\text { Anlaml1lk } \\
\text { (sig.) }\end{array}$ & İstatistik & $\begin{array}{c}\text { Serbestlik } \\
\text { Derecesi }\end{array}$ & $\begin{array}{c}\text { Anlamlılık } \\
\text { (sig.) }\end{array}$ & Skewness & Kurtosis \\
\hline Düşünce &, 232 & 500 &, 144 &, 724 & 500 &, 097 & $-1,351$ &, 627 \\
Kullanma &, 184 & 500 &, 215 &, 814 & 500 &, 121 &,- 815 & 1,224 \\
\hline
\end{tabular}

Parametrik test varsayımları olan verilerin normal dağılımlı olması, gözlem sayısının 30'dan fazla olması, rastgele seçilmiş olması ve nicel yapıda olması gerekmektedir. Bu varsayımlardan normallik varsayımını gerçekleştirmek amacıyla SPSS paket programında gerçekleştirilen normallik analizi tablosu yukarıda verilmiştir. Kolmogorov-Smirnov veya Shapiro-Wilk değerlerinin 0,05'ten büyük olması verilerin normal dağıldı̆̆ını göstermektedir (Hair vd. 1988). Ayrıca sosyal bilimlerde verilerin normal dağıldığını kabul edebilmek için normallik testi sonucunda bakabileceğimiz bir diğer yer ise Skewness ve Kurtosis değerleridir (Tabasnick, B.G. ve Fidell L.S. (2013). Bu değerlerin -1,5 ile $+1,5$ değerleri arasında olması sosyal bilimler alanında verilerin normal dağılıma sahip olduğunu söylemek için yeterlidir. Tabloda görüleceği gibi bu değerler istenen aralıkta olduğundan verilerin normal dağılıma sahip olduğu söylenebilir. Çalışma da rassal olarak belirlenmiş 500 kişiye ulaşılmıştır ve veriler nicel 
niteliktedir. $\mathrm{Bu}$ sebeple parametrik test varsayımlarının tamamı kabul edilmiş olmaktadır. $\mathrm{Bu}$ sebeple çalışma sürecinde analizler gerçekleştirilirken parametrik analizler tercih edilmiştir.

\subsection{Tanımlayıcı İstatistikler}

Katılımcılardan elde edilen verilerden tanımlayıcı istatistiklerle ilgili bilgiler aşağıdaki tablolarda gösterilmiştir.

Tablo 3. Katılımcıların demografik özellikleri

\begin{tabular}{|c|c|c|c|c|}
\hline & & $\mathrm{N}$ & Yüzde (\%) & Kümülatif Yüzde $\left(\sum \%\right)$ \\
\hline \multirow{3}{*}{ 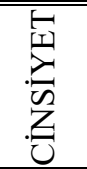 } & Kadın & 178 & 35,6 & $\overline{35,6}$ \\
\hline & Erkek & 322 & 64,4 & 100,0 \\
\hline & Total & 500 & 100,0 & \\
\hline \multirow{8}{*}{$\mathbb{\lambda}_{\lambda}^{\infty}$} & $15-19$ & 117 & 23,4 & 23,4 \\
\hline & $20-24$ & 244 & 48,8 & 72,2 \\
\hline & $25-29$ & 36 & 7,2 & 79,4 \\
\hline & $30-34$ & 28 & 5,6 & 85,0 \\
\hline & $35-39$ & 41 & 8,2 & 93,2 \\
\hline & $40-44$ & 23 & 4,6 & 97,8 \\
\hline & $45-49$ & 5 & 1,0 & 98,8 \\
\hline & $50+$ & 6 & 1,2 & 100,0 \\
\hline \multirow{5}{*}{ 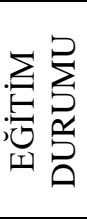 } & Lise & 120 & 24,0 & 24,0 \\
\hline & Ön Lisans & 173 & 34,6 & 58,6 \\
\hline & Lisans & 186 & 37,2 & 95,8 \\
\hline & Yüksek Lisans & 18 & 3,6 & 99,4 \\
\hline & Doktora & 3 & ,6 & 100,0 \\
\hline \multirow{6}{*}{ 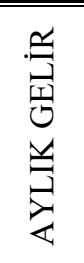 } & 1000 TL ve altı & 207 & 41,4 & 41,4 \\
\hline & $1001-2000$ & 156 & 31,2 & 72,6 \\
\hline & $2001-3000$ & 36 & 7,2 & 79,8 \\
\hline & $3001-4000$ & 39 & 7,8 & 87,6 \\
\hline & $4001-5000$ & 41 & 8,2 & 95,8 \\
\hline & 5000 TL ve üstü & 21 & 4,2 & 100,0 \\
\hline
\end{tabular}

Katılımcılardan yüzde \%35,6’sı (178 kişi) kadın iken, \%64,4’ü (322 kişi) ise kadındır. Katılımcıların \%72,2'si 25 yaşın altında iken \%2,2'si 45 yaş ve daha fazladır. Katılımcıların yaş ortalaması ise 24,2' dir. Eğitim durumunda katılımcıların büyük çoğunluğu \%37,2'si lisans mezunu iken doktora mezunu kişi sayısı 3'tür. Bu da katılımcılar arasında \%0,06'ya tekabül etmektedir. Katılımcıların aylık gelir seviyesine bakıldığında ise \%41,4’ü 1000 TL ve altında gelir elde ettiğini belirtmiştir. Katılımcıların \%72,6’s1 ise günümüz şartlarında asgari ücretten daha düşük seviyede gelir elde ettiğini beyan etmiştir.

\subsection{Fark Testleri}

Katılımcılardan elde edilen veriler doğrultusunda değişken grupları arasında farklılık olup olmadığını test etmek amacıyla çok cevaplı değişkenler için one way anova testi, çift 
cevaplı değişkenler için ise bağımsız örneklem t-testi uygulanmıştır. Analiz sonucunda elde edilen tablolar aşağıda gösterilmiştir.

Tablo 4. Yaş ile faktörler arasındaki fark analizi (ANOVA)

\begin{tabular}{|c|c|c|c|c|c|c|}
\hline \multicolumn{2}{|c|}{} & $\begin{array}{c}\text { Kareler } \\
\text { Toplamı }\end{array}$ & $\begin{array}{c}\text { Serbestlik } \\
\text { Derecesi }\end{array}$ & $\begin{array}{c}\text { Karaler } \\
\text { Ortalamas1 }\end{array}$ & F & $\begin{array}{c}\text { Anlaml1l1k } \\
\text { (sig.) }\end{array}$ \\
\hline \multirow{3}{*}{ Güvenilirlik } & Gruplar Aras1 & 44,025 & 7 & 6,289 & 7,859 &, 000 \\
& Gruplar İçi & 393,709 & 492 &, 800 & & \\
& Toplam & 437,734 & 499 & & &, 000 \\
\multirow{3}{*}{ Kolaylık } & Gruplar Aras1 & 64,657 & 7 & 9,237 & 11,495 & \\
& Gruplar İçi & 395,337 & 492 &, 804 & & \\
& Toplam & 459,993 & 499 & & & \\
\hline
\end{tabular}

Yukarıdaki tabloda katılımcıların yaş gruplarına göre bankacılık sektöründe yapay zekanın güvenilirliği ve kolaylığı açısından farklılık olup olmadığına bakıldığında her iki faktör açısından da anlamlı bir farklılık olduğu görülmektedir $(\mathrm{p}<0,05)$. Bu farklılığın hangi gruplar arasında olduğunu tespit etmek amaciyla post hoc testlerinden Bonferroni analizi uygulanmış ve sonuçlar aşağıdaki tabloda gösterilmiştir.

Tablo 5. Katılımcıların yaş durumu karşılaştırılması

\begin{tabular}{|c|c|c|c|c|c|c|c|}
\hline \multirow{2}{*}{ Bağımlı Değişkenler } & \multirow{2}{*}{ (I) Yaşınız } & \multirow{2}{*}{ (J) Yaşınız } & \multirow{2}{*}{$\begin{array}{l}\text { Ortalamadan } \\
\text { Farklar (I-J) }\end{array}$} & \multirow{2}{*}{$\begin{array}{c}\text { Standart } \\
\text { Hata }\end{array}$} & \multirow{2}{*}{$\begin{array}{c}\text { Anlamlılık } \\
\text { (sig.) }\end{array}$} & \multicolumn{2}{|c|}{ 95\% Güven Aralığı } \\
\hline & & & & & & Alt Sinır & $\overline{\text { Üst Sınır }}$ \\
\hline \multirow{2}{*}{ Güvenilirlik } & $15-19$ & $\begin{array}{c}20-24 \\
25-29 \\
30-34 \\
35-39 \\
40-44 \\
45-49 \\
50 \text { ve üstü } \\
\end{array}$ & $\begin{array}{l}-, 46529^{*} \\
-, 69200^{*} \\
-, 77250^{*} \\
-, 98517^{*} \\
-, 66491^{*} \\
-, 75311 \\
, 13736 \\
\end{array}$ & $\begin{array}{l}, 10059 \\
, 17049 \\
, 18820 \\
, 16235 \\
, 20404 \\
, 40851 \\
, 37445 \\
\end{array}$ & $\begin{array}{l}, 000 \\
, 002 \\
, 001 \\
, 000 \\
, 033 \\
1,000 \\
1,000 \\
\end{array}$ & $\begin{array}{c}-, 7812 \\
-1,2275 \\
-1,3636 \\
-1,4951 \\
-1,3058 \\
-2,0362 \\
-1,0387 \\
\end{array}$ & $\begin{array}{l}-, 1493 \\
-, 1565 \\
-, 1814 \\
-, 4752 \\
-, 0241 \\
, 5300 \\
1,3135 \\
\end{array}$ \\
\hline & $20-24$ & $\begin{array}{c}15-19 \\
25-29 \\
30-34 \\
35-39 \\
40-44 \\
45-49 \\
50 \text { ve üstü }\end{array}$ & $\begin{array}{l}, 46529^{*} \\
-, 22671 \\
-, 30721 \\
-, 51988^{*} \\
-, 19962 \\
-, 28782 \\
, 60265\end{array}$ & $\begin{array}{l}, 10059 \\
, 15971 \\
, 17849 \\
, 15099 \\
, 19512 \\
, 40413 \\
, 36966\end{array}$ & $\begin{array}{c}, 000 \\
1,000 \\
1,000 \\
, 017 \\
1,000 \\
1,000 \\
1,000\end{array}$ & $\begin{array}{l}, 1493 \\
-, 7283 \\
-, 8678 \\
-, 9941 \\
-, 8125 \\
-1,5572 \\
-, 5584\end{array}$ & $\begin{array}{c}, 7812 \\
, 2749 \\
, 2534 \\
-, 0456 \\
, 4132 \\
, 9815 \\
1,7637\end{array}$ \\
\hline \multirow{2}{*}{ Kolaylık } & $15-19$ & $\begin{array}{c}20-24 \\
25-29 \\
30-34 \\
35-39 \\
40-44 \\
45-49 \\
50 \text { ve üstü }\end{array}$ & $\begin{array}{c}-, 48447^{*} \\
-, 76686^{*} \\
-1,01245^{*} \\
-1,16779^{*} \\
-, 93567^{*} \\
-1,18784 \\
-, 23599\end{array}$ & $\begin{array}{l}10080 \\
, 17085 \\
, 18859 \\
, 16268 \\
, 20446 \\
, 40936 \\
, 37522\end{array}$ & $\begin{array}{l}, 000 \\
, 000 \\
, 000 \\
, 000 \\
, 000 \\
, 109 \\
1,000\end{array}$ & $\begin{array}{l}-, 8011 \\
-1,3035 \\
-1,6048 \\
-1,6788 \\
-1,5779 \\
-2,4736 \\
-1,4145\end{array}$ & $\begin{array}{l}-, 1679 \\
-, 2303 \\
-, 4201 \\
-, 6568 \\
-, 2935 \\
, 0979 \\
, 9425\end{array}$ \\
\hline & $20-24$ & $\begin{array}{c}15-19 \\
25-29 \\
30-34 \\
35-39 \\
40-44 \\
45-49 \\
50 \text { ve üstü }\end{array}$ & $\begin{array}{c}, 48447^{*} \\
-, 28238 \\
-, 52797 \\
-, 68332^{*} \\
-, 45120 \\
-, 70337 \\
, 24848\end{array}$ & $\begin{array}{l}, 10080 \\
, 16004 \\
, 17886 \\
, 15130 \\
, 19552 \\
40497 \\
, 37043\end{array}$ & $\begin{array}{c}, 000 \\
1,000 \\
, 093 \\
, 000 \\
, 600 \\
1,000 \\
1,000\end{array}$ & $\begin{array}{c}, 1679 \\
-, 7851 \\
-1,0898 \\
-1,1585 \\
-1,0653 \\
-1,9753 \\
-, 9150\end{array}$ & $\begin{array}{c}, 8011 \\
, 2203 \\
, 0338 \\
-, 2081 \\
, 1629 \\
, 5686 \\
1,4119\end{array}$ \\
\hline
\end{tabular}


Yukarıdaki tabloya bakıldığında yapay zekâya karşı güvenilirlik algısı açısından yaş grupları arasında anlamlı farklılık 15-19 yaşındakiler ile diğer yaş grupları arasında olduğu görülmektedir. 45 yaşından daha büyük olanlar ile anlamlı bir farklılık çıkmamıştır. Bunun nedeni 45 yaşından büyük kişi sayısının yetersiz olmasından kaynaklanmaktadır. Gruplar arasındaki dağılımın çok farklı olması analiz sonuçlarının yanlış çıkmasına neden olabilmektedir. Benzer şekilde 20-24 yaş grubundakiler ile 15-19 ve 35-39 yaş grupları arasında istatistiksel açıdan anlamlı bir farklılık bulunduğu söylenebilir. Kullanım kolaylığı veya ulaşılabilirlik açısından yaş grupları arasındaki farklılığa baktığımızda ise aynı sonuçlar elde edildiği görülmektedir.

Tablo 6. Eğitim durumu ile faktörler arasındaki fark analizi (ANOVA)

\begin{tabular}{|cc|c|c|c|c|c|}
\hline & Kareler Toplamı & $\begin{array}{c}\text { Serbestlik } \\
\text { Derecesi }\end{array}$ & $\begin{array}{c}\text { Karaler } \\
\text { Ortalaması }\end{array}$ & $\begin{array}{c}\text { F } \\
\text { İstatistiği }\end{array}$ & $\begin{array}{c}\text { Anlamlılık } \\
\text { (sig.) }\end{array}$ \\
\hline \multirow{3}{*}{ Güvenilirlik } & Gruplar Arası & 43,596 & 4 & 10,899 & 13,688 &, 000 \\
& Gruplar İçi & 394,137 & 495 &, 796 & & \\
& Toplam & 437,734 & 499 & & & \\
\hline \multirow{3}{*}{ Kolaylık } & Gruplar Arası & 39,964 & 4 & 9,991 & 11,774 &, 000 \\
& Gruplar İçi & 420,029 & 495 &, 849 & & \\
& Toplam & 459,993 & 499 & & & \\
\hline
\end{tabular}

Yukarıdaki tabloda katılımcıların eğitim durumlarına göre bankacılık sektöründe yapay zekânın güvenilirliği ve kolaylığı açısından farklılık olup olmadığına bakıldığında her iki faktör açısından da anlamlı bir farklılık olduğu görülmektedir $(\mathrm{p}<0,05)$. Bu farklılığın hangi gruplar arasında olduğunu tespit etmek amacıyla post hoc. Testlerinden Bonferroni analizi uygulanmış ve sonuçlar aşağıdaki tabloda gösterilmiştir.

Tablo 7. Katılımcıların eğitim durumu karşılaştırılması

\begin{tabular}{|c|c|c|c|c|c|c|c|}
\hline \multirow{2}{*}{$\begin{array}{c}\text { Bağımlı } \\
\text { Değişken }\end{array}$} & \multirow{2}{*}{$\begin{array}{l}\text { (I) Eğitim } \\
\text { Durumu }\end{array}$} & \multirow{2}{*}{$\begin{array}{l}\text { (J) Eğitim } \\
\text { Durumu }\end{array}$} & \multirow{2}{*}{$\begin{array}{l}\text { Ortalamadan } \\
\text { Farklar (I-J) }\end{array}$} & \multirow{2}{*}{$\begin{array}{c}\text { Standart } \\
\text { Hata }\end{array}$} & \multirow{2}{*}{$\begin{array}{l}\text { Anlamlılık } \\
\text { (sig) }\end{array}$} & \multicolumn{2}{|c|}{ 95\% Güven Aralığı } \\
\hline & & & & & & Alt Sinır & Üst Sinır \\
\hline \multirow{4}{*}{ Güvenilirlik } & \multirow{4}{*}{ Lise } & Önlisans &,$- 53484^{*}$ & ,10601 &, 000 &,- 8338 &,- 2359 \\
\hline & & Lisans &,$- 71893^{*}$ & , 10448 &, 000 & $-1,0135$ &,- 4243 \\
\hline & & Yüksek Lisans &,$- 98929^{*}$ & ,22555 & ,000 & $-1,6253$ &,- 3533 \\
\hline & & Doktora &,- 75119 & ,52158 & 1,000 & $-2,2219$ &, 7195 \\
\hline \multirow{4}{*}{ Kolaylık } & \multirow{4}{*}{ Lise } & Önlisans &,$- 54020^{*}$ & , 10944 & ,000 &,- 8488 &,- 2316 \\
\hline & & Lisans &,$- 67315^{*}$ & , 10786 &, 000 &,- 9773 &,- 3690 \\
\hline & & Yüksek Lisans &,$- 99414^{*}$ & ,23284 &, 000 & $-1,6507$ &,- 3376 \\
\hline & & Doktora &,- 48796 & ,53844 & 1,000 & $-2,0062$ & 1,0303 \\
\hline
\end{tabular}

*. Ortalama fark 0.05 düzeyinde anlamlıdır.

Yukarıdaki tabloya bakıldığında katılımcıların eğitim durumu göre bankacılık sektöründe yapay zekaya duyulan güven ile kolaylık algısı açısından istatistiksel açıdan anlamlı farklılık lise grubundaki kişiler ile ön lisans, lisans ve yüksek lisans grubundaki kişiler arasında olduğu görülmektedir. Bunun nedeni olarak, eğitim seviyesi arttıkça kişilerin teknolojik 
gelişmelere ve değişimlere daha açık olması ve bu değişimden daha fazla yararlanmaya çalışmaları söylenebilir.

Tablo 8. Aylık gelir ve faktörler arasındaki fark analizi (ANOVA)

\begin{tabular}{|c|c|c|c|c|c|c|}
\hline & & Kareler Toplamı & $\begin{array}{c}\text { Serbestlik } \\
\text { Derecesi }\end{array}$ & $\begin{array}{c}\text { Karaler } \\
\text { Ortalaması }\end{array}$ & $\mathbf{F}$ & $\underset{\text { (sig.) }}{\text { Anlamlılık }}$ \\
\hline Güvenilirlik & $\begin{array}{c}\text { Gruplar Arası } \\
\text { Gruplar İçi } \\
\text { Toplam } \\
\end{array}$ & $\begin{array}{c}37,523 \\
400,211 \\
437,734 \\
\end{array}$ & $\begin{array}{c}4 \\
495 \\
499 \\
\end{array}$ & $\begin{array}{c}9,381 \\
, 809\end{array}$ & 11,602 &, 000 \\
\hline Kolaylık & $\begin{array}{c}\text { Gruplar Arası } \\
\text { Gruplar İçi } \\
\text { Toplam }\end{array}$ & $\begin{array}{c}55,146 \\
404,847 \\
459,993\end{array}$ & $\begin{array}{c}4 \\
495 \\
499 \\
\end{array}$ & $\begin{array}{c}13,787 \\
, 818\end{array}$ & 16,857 & ,000 \\
\hline
\end{tabular}

Yukarıdaki tabloda katılımcıların aylık gelir seviyelerine göre bankacılık sektöründe yapay zekânın güvenilirliği ve kolaylığı açısından farklılık olup olmadığına bakıldığında her iki faktör açısından da anlamlı bir farklılık olduğu görülmektedir $(\mathrm{p}<0,05)$. Bu farklılı̆̆ın hangi gruplar arasında olduğunu tespit etmek amaciyla post hoc. testlerinden, Bonferroni analizi uygulanmış ve sonuçlar aşağıdaki tabloda gösterilmiştir.

Tablo 9. Katılımcıların meslek durumu karşılaşstırılması

\begin{tabular}{|c|c|c|c|c|c|c|c|}
\hline \multirow{2}{*}{$\begin{array}{c}\text { Bağımlı } \\
\text { Değişken }\end{array}$} & \multirow{2}{*}{$\begin{array}{l}\text { (I) Aylık Kişisel } \\
\text { Geliriniz }\end{array}$} & \multirow{2}{*}{$\begin{array}{l}\text { (J) Aylık Kişisel } \\
\text { Geliriniz }\end{array}$} & \multirow{2}{*}{$\begin{array}{c}\text { Ortalamadan } \\
\text { Farklar (I-J) }\end{array}$} & \multirow{2}{*}{$\begin{array}{c}\text { Standart } \\
\text { Hata }\end{array}$} & \multirow{2}{*}{$\begin{array}{c}\text { Anlamlılık } \\
\text { (sig.) }\end{array}$} & \multicolumn{2}{|c|}{ 95\% Güven Aralığı } \\
\hline & & & & & & Alt Sinır & Üst Sınır \\
\hline \multirow{8}{*}{ Güvenilirlik } & \multirow{4}{*}{$1000 \mathrm{TL}$ ve alt 1} & $1000 \mathrm{TL}-2000 \mathrm{TL}$ &,$- 37967^{*}$ & ,09126 &, 000 &,- 6370 &,- 1224 \\
\hline & & $3000 \mathrm{TL}-4000 \mathrm{TL}$ &,$- 55994^{*}$ & , 15404 & ,003 &,- 9943 &,- 1256 \\
\hline & & $4000 \mathrm{TL}-5000 \mathrm{TL}$ &,$- 84130^{*}$ &, 15243 &, 000 & $-1,2711$ &,- 4115 \\
\hline & & 5000 TL ve üzeri &,$- 57865^{*}$ & ,20498 & 049 & $-1,1566$ &,- 0007 \\
\hline & \multirow{4}{*}{$1000 \mathrm{TL}-2000 \mathrm{TL}$} & 1000 TL ve alt1 &, $37967^{*}$ & ,09126 & ,000 &, 1224 & 6370 \\
\hline & & $3000 \mathrm{TL}-4000 \mathrm{TL}$ &,- 18027 & ,15819 & 1,000 &,- 6263 & ,2658 \\
\hline & & $4000 \mathrm{TL}-5000 \mathrm{TL}$ &,$- 46163^{*}$ & , 15663 &, 034 &,- 9033 &,- 0200 \\
\hline & & 5000 TL ve üzeri &,- 19898 & ,20812 & 1,000 &,- 7858 & ,3878 \\
\hline \multirow{8}{*}{ Kolaylık } & \multirow{4}{*}{1000 TL ve alt 1} & $1000 \mathrm{TL}-2000 \mathrm{TL}$ &,$- 48002^{*}$ & ,09178 &, 000 &,- 7388 &,- 2212 \\
\hline & & $3000 \mathrm{TL}-4000 \mathrm{TL}$ &,$- 74867^{*}$ & , 15493 &, 000 & $-1,1855$ &,- 3118 \\
\hline & & $4000 \mathrm{TL}-5000 \mathrm{TL}$ &,$- 99522^{*}$ & ,15331 & ,000 & $-1,4275$ &,- 5629 \\
\hline & & 5000 TL ve üzeri &,- 56600 & ,20616 &, 063 & $-1,1473$ &, 0153 \\
\hline & \multirow{4}{*}{$1000 \mathrm{TL}-2000 \mathrm{TL}$} & 1000 TL ve alt1 &, $48002^{*}$ & ,09178 & 000 & ,2212 & ,7388 \\
\hline & & $3000 \mathrm{TL}-4000 \mathrm{TL}$ &,- 26865 & , 15911 & ,919 &,- 7173 &, 1800 \\
\hline & & $4000 \mathrm{TL}-5000 \mathrm{TL}$ &,$- 51520^{*}$ & , 15753 &, 011 &,- 9594 &,- 0710 \\
\hline & & 5000 TL ve üzeri &,- 08598 & 20932 & 1,000 &,- 6762 &, 5042 \\
\hline
\end{tabular}

*. Ortalama fark 0.05 düzeyinde anlamlıdır.

Yukarıdaki tabloya bakıldığında katılımcıların gelir seviyesine göre bankacılık sektöründe yapay zekâya duyulan güven ile kolaylık algısı açısından istatistiksel açıdan anlamlı farklılık 1000 TL'nin altında gelir elde eden kişiler ile daha fazla gelir elde eden kişiler arasında istatistiksel açıdan anlamlı bir farklılık bulunmaktadır $(\mathrm{p}<0,05)$. Bunun nedeni gelir seviyesi azaldıkça kişilerin bankacılık uygulamalarına duydukları ihtiyaç azalacağından yapay zekânın etkisinin bankacılık sektöründe bu kişiler açısından önemsizleşmesi gösterilebilir. 
Tablo 10. Cinsiyet ve faktörler arasındaki fark analizi

\begin{tabular}{|c|c|c|c|c|c|c|c|}
\hline & \multicolumn{2}{|c|}{$\begin{array}{l}\text { Eşit Varyanslarda } \\
\text { Levene'nin Testi }\end{array}$} & \multicolumn{5}{|c|}{ Eşit Ortalamalarda t-testi } \\
\hline & $\underset{\text { istatistiği }}{\mathrm{F}}$ & $\begin{array}{l}\text { Anlamlilik } \\
\text { (sig.) }\end{array}$ & $\frac{\mathrm{T}}{\text { istatistiğ } \mathrm{i}}$ & $\begin{array}{l}\text { Serbestlik } \\
\text { Derecesi }\end{array}$ & $\begin{array}{l}\text { Anlamlilik (sig.) } \\
\text { (2-kuyruklu) }\end{array}$ & $\begin{array}{c}\text { Ortalamadan } \\
\text { Farklar }\end{array}$ & $\begin{array}{c}\text { Standart } \\
\text { Hatalar Aras1 } \\
\text { Mesafe }\end{array}$ \\
\hline $\begin{array}{l}\text { Güvenilirlik } \\
\text { Kolaylık }\end{array}$ & $\begin{array}{l}2,157 \\
2,568\end{array}$ & $\begin{array}{l}, 143 \\
, 110\end{array}$ & $\begin{array}{l}1,945 \\
3,016\end{array}$ & $\begin{array}{l}498 \\
498\end{array}$ & $\begin{array}{l}, 052 \\
, 003\end{array}$ & $\begin{array}{l}, 16971 \\
26827\end{array}$ & $\begin{array}{l}, 08724 \\
, 08896\end{array}$ \\
\hline
\end{tabular}

Katılımcılardan elde edilen veriler doğrultusunda katılımcıların kadın veya erkek olması bankacılık sektöründe yapay zekâ kullanımına duyulan güveni veya bankacılık işlemlerini yapay zekânın kolaylaştırıcı etkisi olduğu düşüncesini etkileyip etkilemediği konusunda farklılığa neden olup olmadığını tespit etmek amacıyla SPSS paket programında bağımsız örneklem t-testi uygulanmıştır. Uygulanan test sonucu yukarıdaki tabloda gösterilmiştir. Tabloya göre katılımcıların cinsiyeti yapay zekâya duyulan güven algısı açısından anlamlı bir farklılığa neden olmamaktadır $(0,052>0,05)$. Ancak cinsiyete göre kolaylık açısından anlamlı bir farklılık olduğu görülmektedir $(0,003<0,05)$.

\section{3. İlișki Testleri}

Bankacılık sektöründe yapay zeka kullanımının katılımcıların güven algıları ve bankacılık işlemlerini gerçekleştirirken duydukları kolaylık algıları ile diğer değişkenler arasında ilişki olup olmadığına bakmak amacıyla SPSS paket programında korelasyon (ilişki) analizi gerçekleştirilmiştir. Analiz sonuçları aşağıdaki tabloda gösterilerek tablo altında yorumlanmıştır.

Tablo 11. Korelasyon analizi

\begin{tabular}{|c|c|c|c|c|c|c|c|}
\hline & & Güvenilirlik & Kolaylık & Cinsiyetiniz & Yaşınız & $\begin{array}{c}\text { Eğitim } \\
\text { Durumunuz }\end{array}$ & $\begin{array}{c}\text { Aylık } \\
\text { Kişisel } \\
\text { Geliriniz }\end{array}$ \\
\hline \multirow[b]{2}{*}{ Güvenilirlik } & $\begin{array}{c}\text { Pearson } \\
\text { Korelasyon }\end{array}$ & 1 &, $903^{* * *}$ &,- 087 &, $212^{* *}$ &, $298^{* *}$ &, $263^{* *}$ \\
\hline & $\begin{array}{c}\text { Anlamlılık } \\
\text { (sig.) (2- } \\
\text { kuyruklu) }\end{array}$ & & ,000 &, 052 & ,000 & ,000 &, 000 \\
\hline \multirow{3}{*}{ Kolaylık } & $\begin{array}{c}\text { Pearson } \\
\text { Korelasyon }\end{array}$ & & 1 &,$- 134^{* *}$ &, $302^{* *}$ &, $269^{* *}$ &, $299^{* *}$ \\
\hline & $\begin{array}{l}\text { Anlamlılık } \\
\text { (sig.) (2- } \\
\text { kuyruklu) }\end{array}$ & & & ,003 &, 000 &, 000 & ,000 \\
\hline & $\mathrm{N}$ & 500 & 500 & 500 & 500 & 500 & 500 \\
\hline
\end{tabular}

**. Korelasyon 0.01 düzeyinde anlamlıdır (2-kuyruklu). 
Yukarıdaki tabloda sig. değerleri değişkenler arasındaki ilişkinin istatistiksel açıdan anlamlı olup olmadığını göstermektedir. Sosyal bilimler alanında sig. değerinin 0,05 'ten küçük olması değişkenler arasında anlamlı bir ilişki olduğunu kabul etmek için yeterlidir. Ancak bu çalışmadan elde edilen sonuçlar 0,01 anlamlılık düzeyinde istatistiksel açıdan anlamlı bir ilişki olduğunu göstermektedir. Korelasyon katsayısı ise değişkenler arasındaki ilişkinin yönü hakkında bilgi vermektedir. Korelasyon katsayısı pozitif ise değişkenler arası ilişkiler aynı yönlü, negatif ise ters yönlü bir ilişki olduğu söylenebilmektedir. Yukarıdaki tablodan hareketle; bankacılık sektöründe kullanılan yapay zekâ uygulamalarına yönelik katılımcıların kullanımdaki kolaylık algısı arttıkça duydukları güven seviyesi de artmaktadır. Ayrıca eğitim durumu arttıkça bankacılık sektöründeki yapay zekâ uygulamalarına yönelik duyulan güven algısı ve kolaylık algısının arttığı da görülmektedir.

\section{SONUÇ}

Yapay zekâ uygulamaları sayesinde, kasasız ödeme, kart doğrulama kodu ve mobil uygulamalar gibi değişen uygulamalar, günümüzde daha çok tercih edilmektedir. Yaşanan teknolojik gelişmeler ile kullanıcılar, yapay zekâ uygulamalarının, yapılan işlemlerin hızlı ve kolay olması, aynı zamanda güvenilir bir biçimde işlemlerin yürütülmesi açısından olumlu bulmakta ve kullanmaktadırlar. Yapay zekâ otomasyonlarının bankacılık sektöründeki iş biçimini değiştirme ve bu değişime etki ettiği yönünde kullanıcıların yüksek çoğunluğu olumlu fikir beyan etse de bu konu hakkında kesin bir eğilim ortaya konulamamış, yapay zekânın henüz bankacılık sektörüne tam anlamıyla etki ettiği fikri ortaya konulamamıştır. Kullanıcılar yapay zekâ otomasyonlarının bankacılık sektörüne daha ilerleyen zamanlarda tam olarak etki edeceği yönünde fikir beyan etmişlerdir.

Günümüzde kullanılan yapay zekâ uygulamaları kullanıcıların isteklerine göre şekillenmekte, kullanım kolaylığının üst seviyede olması kullanıcıların fikirlerini olumlu yönde etkilemiştir. Sağlanan bu kolaylık sayesinde kullanıcılar hesaplarını anında kontrol edebilmekte, ödeme işlemlerini ve para transferlerini kolayca yapabilmekte, kredi borcunu öğrenebilmekte ve sorgulayabilmekte olması kullanıcılar tarafından bu işlemlerin kolayca yapılabilmesi fikirlerindeki olumlu yönleri ortaya çıkarmıştır. Yapay zekâ uygulamalarının bankacılık sektörüne yönelik geliştirdiği dağıtım kanalları günden güne gelişmekte, kullanıcılar tarafından bankacılık işlemlerinin bu uygulamalar içerisinde kolayca yapılması, zaman ve yer kavramını ortadan kaldırması gibi birtakım etkenler bu uygulamalar sayesinde oluşmuştur. Oluşan bu kolaylıklar sayesinde kullanıcılar anket sorularına verdiği yanıtlar niteliğinde yüksek sayıda yapay zekânın geliştiği ve gelişeceği yönünde fikir ortaya koymuş, yapay zekânın 
hayatlarına etki ettiğini beyan etmiş, bu uygulamalara yönelik olumlu fikirlerini verdikleri yanıtlarla göstermişlerdir.

Gerçekleştirilen analizler sonucunda, kişilerin bankacılık uygulamalarında yapay zekâ kullanıma duydukları güven ile bankacılık uygulamaları arasında pozitif yönlü ve istatistiksel açıdan anlamlı bir ilişki olduğu görülmektedir. Yani kişiler bankacılık uygulamalarını yapay zekânın kolaylaştırdığını hissettikçe yapay zekâya duydukları güven artmaktadır. Ayrıca kişilerin yaşı, eğitim durumu ve aylık gelir seviyesi ile yapay zekâ uygulamalarına duydukları güven arasında istatistiksel açıdan anlamlı ve pozitif yönlü bir ilişki vardır. Kişilerin yaşı, aylık gelir seviyesi ve eğitim düzeyi arttıkça bankacılık sektöründe yapay zekâya kullanımına duyulan güven artmaktadır. Değişkenler arasındaki ilişkilere kolaylık açısından bakıldığında ise cinsiyet ile kolaylık algısı arasında istatistiksel açıdan anlamlı ve negatif/ters yönlü bir ilişki olduğu görülmektedir. Yani kadınlar açısından bankacılık uygulamalarında yapay zekânın kullanımında algılanan zorluk seviyesi daha yüksek olmaktadır. Yaş, eğitim durumu ve aylık gelir seviyesi ile kolaylık algısı arasında ise istatistiksel açıdan anlamlı ve pozitif yönlü bir ilişki olduğu görülmektedir. Kişilerin yaşı, eğitim düzeyi ve aylık gelir seviyesi artıkça bankacılık uygulamalarında yapay zekâ kullanım süreçlerinin daha da kolaylaştırdığı algısı artmaktadır.

$\mathrm{Bu}$ çalışmada, yapay zekâ uygulamalarının, finans sektörü ve ağırlıklı olarak bankalardaki işleyişi incelenmiştir. Kullanıcıların yapay zekâyı kullanım kolaylığı ve yapay zekâ uygulamalarına güvenilirliği analiz edilmiştir. Finans kurumlarında kullanılan yapay zekâ otomasyonlarının kolaylık sağladığı ve güvenilirliğinde farklı faktörlere göre değişiklik gösterdiği sonucuna ulaşılmıştır. Çalışma sonuçlarına göre, finans kurumlarının geliştireceği yapay zekâ uygulamaları ile bireylerin yer ve mekândan bağımsız şekilde finansal hesaplarına erişebilmesinin, tercih edilebilirliği arttırılabileceği düşünülmektedir. Çalışmada, 15-24 yaş aralığında ve 0-1000 TL ile 1000 - 2000 TL gelir seviyesinde katılımcıların yoğun olduğu görülmektedir. Daha sonra yapılacak çalışmalarda farklı hedef kitle üzerinde uygulama yapılarak, yapay zekâ uygulamalarının önemi ve işleyişi test edilebilir.

\section{KAYNAKÇA}

Aktaş, P. (2018). Banka kavramı. 2019 tarihinde alındı.

Alkan, H., \& Küçüky1lmaz, T. (2018, Mart). Kasasız alışveriş. https://shiftdelete.net: https://shiftdelete.net/kasasiz-odeme-ile-alisveris-yaptik-hediyeli-video adresinden alınmıştır.

Aras, G. (1999). Ticari Bankalarda Kredi Portföyünün Yönetimi.

Armağan, E. (2016). Türkiye'de İnteRnet Bankacılığı Kullanımında Demografik Faktörlerin Tüketici Algısına Etkisi Üzerine Ampirik Bir Çalışma. CBÜ Sosyal Bilimler Dergisi , 411-436. 
Barutçu, S. (2010). "Mobil Pazarlama” (Derl. İ. Varinli ve K. Çatı). Güncel Pazarlama Yaklaşımlarından Seçmeler. Ankara: detay yayıncılık.

Codevist. (2018, Ağustos). Fintek (Fintech) Nedir? 2019 tarihinde https://blog.codevist.com/fintech-nedir-8c57d871b2b8 adresinden alınd1.

Döldöş, İ. (2017). Fintech Nedir ? 2019 tarihinde https://startuphukuku.com: https://startuphukuku.com/fintech-nedir/ adresinden alındı.

Denizbank. (2019). Internet Bankacılı̆̆ı'ndan Yapılabilen İşlemler. 2019 tarihinde https://www.denizbank.com: https://www.denizbank.com/bilgiliman/question/2/16.aspx adresinden alındı.

Dişbudak, C. (2018). Fintech Alanında Girişimciliğin Türkiye'deki Geleceği. 2019 tarihinde https://www.paradurumu.com/teknoloji/fintech-alaninda-girisimciligin-turkiyedeki-gelecegihaberi-2705\#page_7 adresinden alınd1.

Doğan, E. (2012). Banka ve Bankacılık Kavramları. İstanbul: Beta Yayıncılık.

Ercişli, N. (2007). Yüksek Lisans Tezi. Internet Bankacılı̆̆ı Uygulamaları Ve İşletme Performansı Üzerine Etkileri: Denizbank Örnek Olay Çalışması . Konya: Selçuk Üniversitesi Sosyal Bilimler Enstitüsü.

Eriş, H. (2013). Bankacılık Hizmet Ürünleri. Anadolu Üniversitesi.

Fintech, İ. (2017, Mart). İzlenmesi Gereken 12 FinTech Şirketi. 2019 tarihinde https://fintechistanbul.org/2017/03/04/izlenmesi-gereken-12-fintech-sirketi/ adresinden alınd1.

Gülyüz, F. (2018, Aralık). CVV Kodu Nedir? Kartın Neresinde Yazar? 2019 tarihinde https://www.dunyapara.com/cvv-kodu-nedir/ adresinden alınd1.

Güney, A. (2012). Banka Muhasebesi. içinde İstanbul: Beta yayıncılık.

Gürtuna, s. m. (2005). Yüksek Lisans Tezi. Türkiye'de Bankacılık Sektörünün Gelişimi ve Reel Kesime Etkisi . İstanbul: İstanbul Üniversitesi Sosyal Bilimler Enstitüsü İktisat Anabilim Dalı.

Işkın, S. (2012). Elektronik Bankacılık Hizmetleri Ve Denetimi. İstanbul: İTO Yayınları.

İşler, A. U. (2015). Yüksek Lisans Tezi. Bankacılık sektöründe internet ve mobil bankacılık kullanımının ehizmet tarafından kullanılmasının değerlendirilmesi. Karabük Üniversitesi Sosyal Ana Bilim Dalı Enstitüsü.

Karabıyık, L. (2004). Küreselleşme Sürecinde Finansal Krizler Ve Etkileri. Bursa: Marmara Kitabevi.

Keskin, S. (2017, Aralık). Doktora Tezi. internet bankacılı̆̆ında tüketici motivasyonunun davranışsal etkileri. Nevşehir Hacı Bektaş Veli Üniversitesi.

Market Palace, A. (2016, Mayis). https://www.atmmarketplace.com/news/idea-bank-mobileatm-fleet-grows-in-popularity-and-size/ adresinden alınmıştır.

Okumuş, A., Bozbay, Z., \& Dağlı, R. M. (2010). Banka Müşterilerinin internet Bankacılığına ilişkin Tutumlarının İncelenmesi. Erciyes Üniversitesi: İBFF Dergisi. 
Önder, S. (1999). Isşletmelerde Internet Kullanımı Ve İnternet Kullanımının Bankacılık Sektöründeki Uygulaması .

Öner, E. (2018, May1s). Giyilebilir Teknoloji. https://www.wowslides.com: https://www.wowslides.com/users/emel.yolcu/projects/2017/07/giyilebilir-teknoloji?slide=4 adresinden alınmıştır.

Öner, E. (2018, May1s). Giyilebilir Teknoloji. https://www.wowslides.com: https://www.wowslides.com/users/emel.yolcu/projects/2017/07/giyilebilir-teknoloji?slide=18 adresinden alınmıştır.

Özcan, Z. Ö. (2007, Ekim). Yüksek Lisans Tezi. Türkiye'de Elektronik Bankacılık: Internet Bankacılı̆̆ Üzerine Bir Çalışma. Sakarya: Sakarya Üniversitesi Sosyal Bilimler Enstitüsü.

Pala, E., \& Kartal, B. (2010). Banka Müşterilerinin İnternet Bankacıllı̆ı ile İlgili Tutumlarına Yönelik Bir Pilot Araştırma. Celal Bayar Üniversitesi I.I. B.F. , 44.

Parasız, İ. (2007). Modern Bankacılık Teori ve Uygulama. içinde İstanbul: Kuşaf Ofset.

Parasız, İ. (2011). Türkiye'de ve Dünya'da Bankacılık. Bursa: Ezgi Kitabevi.

Sönmez , S. (2017, Ocak). ATM'ye Dokunmadan Para Çekme. https://www.dunyahalleri.com/bankaciligi-dijitallestiren-6-yeni-teknoloji/ adresinden alınmıştır.

Sönmez, S. (2017, Ocak 19). Bankacılı̆̆ı Dijitalleştiren 6 Yeni Teknoloji. https://www.dunyahalleri.com/bankaciligi-dijitallestiren-6-yeni-teknoloji/ alınmıştır.

Sönmez, S. (2017, Ocak). Kasasız Alışveriş. https://www.dunyahalleri.com/bankaciligidijitallestiren-6-yeni-teknoloji/ adresinden alınmıştır.

Sallı , B. (2019, Şubat). CVV Kodu Nedir, CVV Nerede Yazar? https://konupara.com/bankalar/kart-guvenlik-kodu-cvv-nedir-8061/ adresinden alınmıştır.

Soydan, B. (2016, Mayıs). Türkiye'nin En Hizlı Büyüyen 10 Fintech Startup'ı. http://www.turkishtimedergi.com/dijital-girisim/turkiyenin-en-hizli-buyuyen-10-fintechstartupi/ adresinden alınmıştır.

Şahin, B. (2018, Mayıs). BKM Express'in Kasasız Alışveriş Projesini Yerinde Deneyimledik. https://digitalage.com.tr/bkm-expressin-kasasiz-alisveris-projesini-yerinde-deneyimledik/ adresinden alınmıştır.

Türkiye İş Bankası. (2016). İşcep Karekod Ile Bankamatikten Para Çekme. https://www.isbank.com.tr/TR/dijital-bankacilik/Documents/qrkod_para_cekme.pdf adresinden alınmıştır.

Takan, M. (2001). Bankacılık Teori, Uygulama Ve Yöntem. Ankara: Nobel yayıncılık.

TBB. (2012, Eylül). “Finans ve Bankacılıkta Sonraki Adım Konferansı. https://www.tbb.org.tr: https://www.tbb.org.tr/Dosyalar/Baskan_Konusmalari/TBB_YKBsk_Bilisim_Zirvesi_Konus ma_metni_120912.pdf adresinden alınmıştır. 
Gümüs, E., Medetoğlu B., Tutar S.

Yalçın, F. (2018, Ağustos). Mobil Cüzdan Dünyası Ve En Sık Kullanılan Uygulamalar. https://fintechistanbul.org/2018/08/31/mobil-cuzdan-dunyasi-ve-en-sik-kullanilanuygulamalar/ adresinden alınmıştır. 